\title{
Highly active and trans-1,4-specific polymerization of 1,3-butadiene catalyzed by bis(benzimidazolyl)amine chromium complexes activated with methylaluminoxane
}

\author{
Byeong Kyu Moon, Ga Young Song, Lin Zhang, Jin Young Shin, Hyuk Chul Chang, \\ Sang Eun Shim*, Ju Ho Yun ${ }^{* *}$, and $\mathrm{Il} \mathrm{Kim}^{\dagger}$ \\ The WCU Center for Synthetic Polymer Bioconjugate Hybrid Materials, Department of Polymer Science and \\ Engineering, Pusan National University, Jangjeon-dong, Geumjeong-gu, Busan 609-735, Republic of Korea \\ "Department of Chemical Engineering, Inha University, 253 Yonghyundong, Namgu, Incheon 402-751, Republic of \\ Korea \\ ${ }^{* *}$ Enviromental Materials \& Components R\&D Center, Korea Automotive Technology Institute 74 Youngjung-Ri, \\ Pungse-Myun, Dongnam-Gu, Chonan-Si, Chungnam 330-912, Republic of Korea \\ (Received December 24, 2012, Revised January 4, 2013, Accepted January 10, 2013)

\section{메틸알루미녹산으로 활성화시킨 고활성 bis(benzimidazolyl)amine 크롬 착물을 이용한 부타디엔 중합에 의한 트랜스 폴리부타디엔 제조} \\ 문병규 · 송가영 · 장린 · 신진영 · 장혁철 · 심상은 ${ }^{\star} \cdot$ 윤주호 $^{\star *} \cdot$ 김일 ${ }^{\dagger}$ \\ 부산대학교 고분자공학과 \\ "인하대학교 화학공학과 \\ **자동차부품연구원 \\ 접수일(2012년 12월 24일), 수정일(2013년 1월 4일), 게재확정일(2013년 1월 10일)
}

\begin{abstract}
A family of $\mathrm{Cr}(\mathrm{III})$ complexes supported on tridentate dibenzimidazolyl ligands having a general formula: $\left[\mathrm{N}\left(\mathrm{CH}_{3}\right)\left(\mathrm{CH}_{2}\right)_{2}(\mathrm{Bm}-\mathrm{R})_{2}\right] \mathrm{CrCl}_{3}$ [where $\mathrm{Bm}=$ benzimidazolyl, $\mathrm{R}=\mathrm{H}(3 \mathrm{a}) ;-\mathrm{Me}(3 \mathrm{~b}) ;-\mathrm{Bn}(3 \mathrm{c})$ ] have been synthesized and utilized them for the trans-1,4-specific polymerizations of 1,3-butadiene (BD), activated with methylalumoxane (MAO). The activity of $\mathrm{BD}$ polymerizations was sensitive to the type of ligand on the $\mathrm{Cr}$ metal, so that the activity decreases in the order of $3 a>3 c>3 b$. All the catalysts combined with MAO yielded polybutadienes with perfect trans-1,4 structure with moderate molecular weight.

요 약 : 일반식을 $\left[\mathrm{N}\left(\mathrm{CH}_{3}\right)\left(\mathrm{CH}_{2}\right)_{2}(\mathrm{Bm}-\mathrm{R})_{2}\right] \mathrm{CrCl}_{3}$ [여기에서 $\mathrm{Bm}=$ benzimidazolyl, $\mathrm{R}=\mathrm{H}(3 \mathrm{a}) ;-\mathrm{Me}(3 \mathrm{~b}) ;-\mathrm{Bn}$ (3c) ] 으로 나타낼 수 있는 일련의 세 다리 dibenzimidazolyl 리간드를 갖는 크롬(III) 착물을 합성, 메틸알루미녹산으 로 활성화시켜 이를 부타디엔의 입체규칙성 중합을 통해 trans-1,4-polybutadiene을 제조하였다. 크롬 착물의 부타 디엔 중합 활성은 리간드의 구조에 따라 달라졌으며, 활성은 $3 \mathrm{a}>3 \mathrm{c}>3 \mathrm{~b}$ 순으로 낮아졌다. 모든 착물을 이용하여 제조된 폴리부타디엔의 미세구조를 조사한 결과 거의 완벽한 trans $-1,4$ 구조를 보였으며, 분자량도 비교적 높게 나타났다.
\end{abstract}

Keywords : polymerization, 1,3-butadiene, organometallic chromium complexes, trans-1,4-polybutadiene, ligand

\section{Introduction}

Many catalytic systems, obtained by combining transition metal (e.g. Ti, V, Cr, Fe, Co, Ni) compounds or lanthanide (e.g. Nd, Pr) compounds with suitable alkylating agents (e.g. AlEt 3 , $\mathrm{AlEt}_{2} \mathrm{Cl}$ ) led to a breakthrough in the field of conjugated diolefin

† Corresponding Author. E-mail: ilkim@pusan.ac.kr polymerization. ${ }^{1-3}$ Four stereoregular polymers were obtained from 1,3-butadiene (BD), having a trans-1,4, cis-1,4, isotactic 1,2 and syndiotactic 1,2 structures, respectively. Specifically the 1,3-dienes polymerization by using catalysts based on transition metal (mainly $\mathrm{Cr}, \mathrm{Fe}, \mathrm{Co}$ ) complexes with phosphorus and nitrogen ligands in combination with methylaluminoxane (MAO) flourished the modulation of the polydiene microstructure by varying the type of ligand and metal. ${ }^{4-6}$ 
Chromium catalysts are well known for giving 1,2-polymers from 1,3-butadiene. ${ }^{7}$ For instance, the system $\mathrm{Cr}(\mathrm{acac})_{3}-\mathrm{AlEt}_{3}$ gave a 1,2-polybutadiene (PBD) with a syndiotactic or an isotactic structure depending on the polymerization conditions (e.g. $\mathrm{Al} / \mathrm{Cr}$ molar ratio); the activity of this system was however rather low. More active and stereospecific catalysts have been recently obtained by combining $\mathrm{Cr}$ (II) phosphine complexes $\left(\mathrm{CrCl}_{2} \cdot \mathrm{Ln}\right.$; L $=$ bidentate phosphines; $\mathrm{n}=1,2$ ) with $\mathrm{MAO}^{8}$ Chromium complexes with $N, N, N$-tridentate ligands, $\mathrm{LCrCl}_{3}[\mathrm{~L}=2,6$-bis $\{(4 \mathrm{~S})$ (-)-isopropyl-2-oxazolin-2-yl\}pyridine], upon activation with modified MAO, was found to have completely trans-1,4 structure. ${ }^{9}$ This paper provides preliminary results on the trans-1,4-specific polymerizations of $\mathrm{BD}$ with a family of $\mathrm{Cr}$ (III) complexes supported on tridentate dibenzimidazolyl ligands having a general formula: $\left[\mathrm{N}\left(\mathrm{CH}_{3}\right)\left(\mathrm{CH}_{2}\right)_{2}(\mathrm{Bm}-\mathrm{R})_{2}\right] \mathrm{CrCl}_{3}$ (where $\mathrm{Bm}$ = benzimidazolyl, $\mathrm{R}=\mathrm{H}$; $-\mathrm{Me}$; $-\mathrm{Bn})$, activated with $\mathrm{MAO}$.

\section{Experimental}

\section{General Methods and Materials}

All manipulations involving air or moisture sensitive compounds were carried out under a purified nitrogen atmosphere using Schlenk technique. All solvents was distilled according to standard procedures. Polymerization grade BD (Keumho Petrochem. Co., Korea) was purified by passing it through columns of Fisher RIDOX $^{\mathrm{TM}}$ catalyst and molecular sieve $5 \AA / 13 \mathrm{X}$. Alkylaluminums such as MAO, EASC, methylaluminum dichloride (MADC) and diethylaluminum chloride (DEAC), all in toluene solutions, were obtained from Aldrich and used without further purification.

\section{Characterization}

UV-VIS spectra were recorded on a Shimadzu UV-1650 PC spectrometer in toluene. The cyclovoltametry (CV) measurements were conducted on a BAS CV-50W voltammetric analyzer with scan rates of $100 \mathrm{mV} \mathrm{sec}{ }^{-1}$. The electrolytic cell used was a conventional three-compartment cell, in which a glass carbon working electrode, a platinum counter electrode, and $\mathrm{Ag} / \mathrm{AgCl}$ reference electrode were employed. Elemental analysis of metal complexes was carried out using Vario EL analyzer. Fast atom bombardment mass spectroscopy (FAB MS) was determined using JMS-700, JEOL instrument. Molecular weight (MW) and molecular weight distribution (MWD) of PBD were determined by gel permeation chromatography (GPC) using a Waters 2414 series system in THF at $25{ }^{\circ} \mathrm{C}$ calibrated with polystyrene standards. ${ }^{1} \mathrm{H}-\mathrm{NMR}$ (300
$\mathrm{MHz}$ ) and ${ }^{13} \mathrm{C}-\mathrm{NMR}(75 \mathrm{MHz})$ spectra were recorded at $25{ }^{\circ} \mathrm{C}$ on a Varian Gemini 2000 spectrometer in $\mathrm{CDCl}_{3}$.

\section{BD Polymerizations}

Solution polymerizations of BD in toluene were carried out in a Fisher-Porter-Bottle $(50 \mathrm{~mL})$ connected with a vacuum line. $1.1 \mu \mathrm{mol}$ of the precatalyst was dissolved in $20 \mathrm{~mL}$ of toluene. After controlling the temperature of reaction mixture $50{ }^{\circ} \mathrm{C}, 0.757$ $\mathrm{g}$ of $\mathrm{BD}$ (to make $0.7 \mathrm{M}$ solution) was equilibrated to toluene. The polymerization started by injecting a prescribed amount of EASC (in general $\mathrm{Al} / \mathrm{Cr}=100$ ) to the solution. After $1 \mathrm{~h}$ of polymerization, the resulting solution mixture was poured into acidified methanol $(50 \mathrm{~mL}$ of a $5 \% \mathrm{v} / \mathrm{v}$ solution of $\mathrm{HCl})$ containing butylhydroxytoluene as stabilizer. The polymer was isolated by filtration and then dried overnight at $50{ }^{\circ} \mathrm{C}$ under vacuum. Polymer yield was determined by gravimetry.

\section{Synthesis of ligands and complexes}

The general procedures for the synthesis of $\mathrm{Cr}$ (III) complexes are summarized in Scheme 1. The bis(benzimidazolyl)amine ligands, $1,2 \mathrm{a}$ and $2 \mathrm{~b}$, were prepared according to the reported procedures. $^{11}$

For the preparation of $3 \mathrm{a}$, a solution of $\mathrm{CrCl}_{3}(\mathrm{THF})_{3}(0.132$ g, $0.350 \mathrm{mmol})$ and ligand $1(0.109 \mathrm{~g}, 0.350 \mathrm{mmol})$ in THF was stirred at room temperature for $24 \mathrm{~h}$, giving a green suspension. The reaction volume was reduced, diethyl ether was added, and a green solid was obtained, which was washed repeatedly with diethyl ether and dried under vacuum. The green powder $(0.122$ g, $0.260 \mathrm{mmol})$ was obtained in a yield of $75.0 \%$. IR $\left(\mathrm{KBr} ; \mathrm{cm}^{-1}\right)$ : $3073(\mathrm{vN}-\mathrm{H}), 1609(\mathrm{vC}=\mathrm{C}), 1590(\mathrm{vC}=\mathrm{N}), 1497,1468(\Omega \mathrm{N}-\mathrm{H})$, 1321, 1147, 998, 826, $754(\Omega \mathrm{N}-\mathrm{H})$. Anal. Calcd. for $\mathrm{C}_{19} \mathrm{H}_{13} \mathrm{Cl}_{3} \mathrm{CrN}_{5}$ : C, 48.59; H, 2.79; N, 14.91. Found: C, 48.30; $\mathrm{H}, 2.80 ; \mathrm{N}, 14.54$. FAB-MS (m/z): $415\left[\mathrm{Cr}^{-} \mathrm{Cl}_{2}\right]^{+}$. Similar procedures were employed for the preparation of complexes $3 \mathrm{~b}$ and 3c. $\mathrm{Cr}(\mathrm{III})$ complex 3 b. Green powder in $95.8 \%$ yield. IR $(\mathrm{KBr}$; $\left.\mathrm{cm}^{-1}\right)$ : 3061, 3024, $1603(\mathrm{vC}=\mathrm{C}), 1589(\mathrm{vC}=\mathrm{C}), 1572(\mathrm{vC}=\mathrm{N})$, 1482, 1346, 764, 749. Anal. Calcd. for $\mathrm{C}_{21} \mathrm{H}_{17} \mathrm{Cl}_{3} \mathrm{CrN}_{5}$ : C, 50.67; H, 3.44; N, 14.07. Found: C, 50.31; H, 3.70; N, 13.84. FAB-MS (m/z): $443\left[\mathrm{Cr}^{-} \mathrm{Cl}_{2}\right]^{+}$. $\mathrm{Cr}(\mathrm{III})$ complex 3c. Green powder in $88.8 \%$ yield. IR ( $\left.\mathrm{KBr} ; \mathrm{cm}^{-1}\right)$ : 3055, 3020, $1594(\mathrm{vC}=\mathrm{C}), 1582(\mathrm{vC}=\mathrm{C})$, $1571(\mathrm{vC}=\mathrm{N})$. Anal. Calcd. for $\mathrm{C}_{31} \mathrm{H}_{29} \mathrm{Cl}_{3} \mathrm{CrN}_{5}$ : C, 59.10; H, 4.64; $\mathrm{N}, 11.12$. Found: C, 59.01; H, 4.70; N, 11.10. FAB-MS (m/z): $595\left[\mathrm{Cr}^{-} \mathrm{Cl}_{2}\right]^{+}$. 


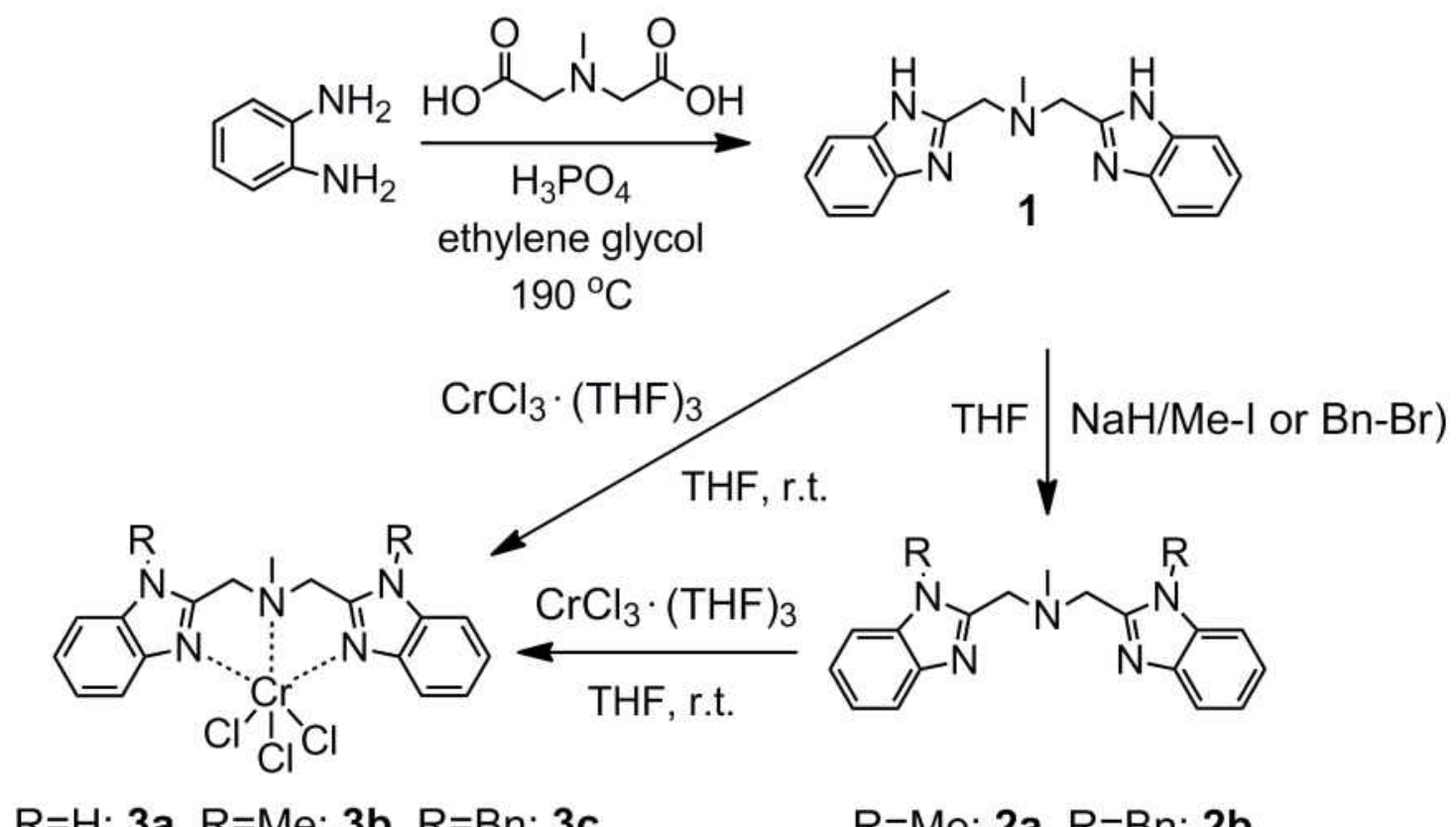

Scheme 1. Synthesis of ligands and metal complexes.

\section{Computational details}

The quantum chemical calculations were performed with the $\mathrm{DMol}^{3}$ density functional theory (DFT) code as implemented in Accelrys Materials Studio ${ }^{\circledR} 4.3$ (http://www.accelrys.com/) on a personal computer $\left(\right.$ Intel $^{\circledR}$ Core $^{\mathrm{TM}}$ i7 $\mathrm{CPU}$ at $3.47 \mathrm{GHz}, 24.00$ gigabytes ram) operated with Microsoft Windows 7 Ultimate $\mathrm{K}^{13}$

\section{Results and Discussion}

The bis(benzimidazolyl)amine ligand 1 was prepared by condensation reaction of 1,2-phenylenediamine and methyliminodiacetic acid in ethylene glycol at $190{ }^{\circ} \mathrm{C} .{ }^{11}$ The ligands $2 \mathrm{a}$ and $2 \mathrm{~b}$ were obtained in high yields through simple $\mathrm{N}$-alkylation by corresponding alkyl halides via sodium salts of 1 in THF. ${ }^{12}$ All of these ligands synthesized were confirmed by elemental analysis and NMR spectroscopy. $\mathrm{Cr}$ (III) complexes $3 \mathrm{a}-3 \mathrm{c}$ were prepared in good yields $(>75 \%)$ via the treatment of corresponding ligands with 1 equiv. of $\mathrm{CrCl}_{3}(\mathrm{THF})_{3}$ in $\mathrm{THF}$ at room temperature (Scheme 1). The green colored Cr(IIII) complexes were consistent with their elemental and FAB-MS analyses as expected.

$\mathrm{Cr}(\mathrm{III})$ complexes with $\mathrm{N}, \mathrm{N}, \mathrm{N}$-tridentate ligands, $\mathrm{LCrCl}_{3}[\mathrm{~L}$ $=2,6$-bis $\{(4 \mathrm{~S})-(-)$-isopropyl-2-oxazolin-2-yl $\}$ pyridine and 2,2

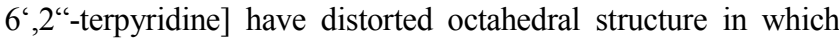
three chloride ligands have meridional geometry. ${ }^{9}$ A theoretical

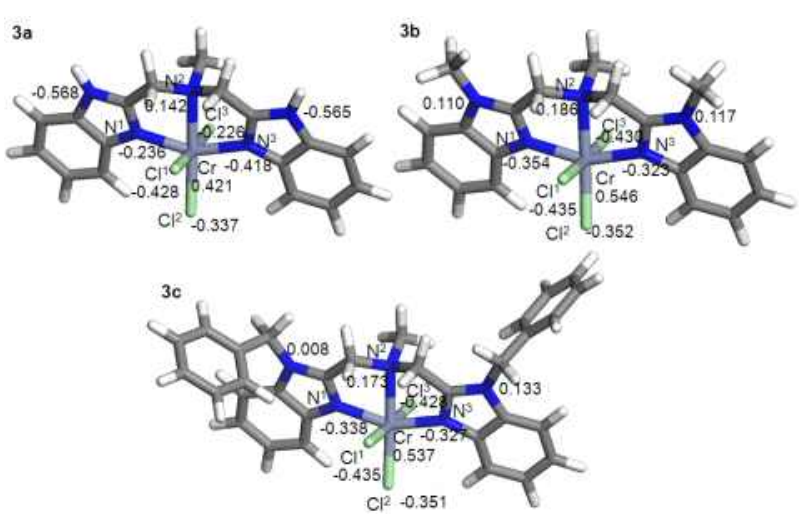

Figure 1. Density functional theory based geometry optimized structure of the complexes. The values given are electro-static potential fitting charges of the corresponding atoms.

calculation was performed to find out the minimum energy structure (Figure 1) of all the $\mathrm{Cr}(\mathrm{III})$ complexes $(3 \mathrm{a}-3 \mathrm{c}$ ) bearing bis(benzimidazolyl)amine ligand. The final structure was obtained using a non-local generalized gradient approximation (GGA) functional by Perdew-Burke-Ernzerhof (PBE) ${ }^{14}$ with the DMol $^{3}$ DFT code.

A polarized split valence basis set, termed double numeric polarized (DNP) basis set was used. The complexes were fully optimized and a few selected geometric parameters and calculation results are given in Table 1. From the optimized structures of 
Table 1. Some important bond lengths, bond angles and parameters estimated for the complexes $3 a-3 c$ by geometry optimization.

\begin{tabular}{lccr}
\hline \multicolumn{1}{c}{ Parameters } & $3 \mathrm{a}$ & $3 \mathrm{~b}$ & $3 \mathrm{c}$ \\
\hline & \multicolumn{4}{c}{ Bond length $(\AA)$} \\
$\mathrm{Cr}-\mathrm{N}^{1}$ a & 2.087 & 2.081 & 2.087 \\
$\mathrm{Cr}-\mathrm{N}^{2}$ & 2.301 & 2.286 & 2.284 \\
$\mathrm{Cr}-\mathrm{N}^{3}$ & 2.092 & 2.093 & 2.089 \\
$\mathrm{Cr}-\mathrm{Cl}^{1}$ & 2.378 & 2.388 & 2.391 \\
$\mathrm{Cr}-\mathrm{Cl}^{2}$ & 2.268 & 2.271 & 2.318 \\
$\mathrm{Cr}-\mathrm{Cl}^{3}$ & 2.316 & 2.318 & 2.318 \\
& \multicolumn{4}{c}{ Bond angle (degree) } \\
$\mathrm{N}^{1}-\mathrm{Cr}-\mathrm{N}^{2}$ & 77.088 & 77.128 & 76.952 \\
$\mathrm{~N}^{2}-\mathrm{Cr}-\mathrm{N}^{3}$ & 77.478 & 77.354 & 77.524 \\
$\mathrm{~N}^{1}-\mathrm{Cr}-\mathrm{Cl}^{1}$ & 89.186 & 89.059 & 88.603 \\
$\mathrm{~N}^{1}-\mathrm{Cr}-\mathrm{Cl}^{2}$ & 102.319 & 102.528 & 102.577 \\
$\mathrm{Cl}^{1}-\mathrm{Cr}-\mathrm{Cl}^{2}$ & 91.840 & 91.553 & 91.373 \\
$\mathrm{Cl}^{1}-\mathrm{Cr}-\mathrm{Cl}^{3}$ & 175.904 & 176.195 & 176.252 \\
& \multicolumn{3}{c}{ Important parameters } \\
$\mathrm{Optimized} \mathrm{energy} \mathrm{(Ha)}^{2}$ & -3355.64 & -3434.17 & -3895.84 \\
$\mathrm{Binding} \mathrm{energy} \mathrm{(Ha)}^{\mathrm{H}}$ & -7.8312 & -8.7763 & -12.9209 \\
$\mathrm{HOMO} \mathrm{Energy} \mathrm{(Ha)}^{\mathrm{b}}$ & -0.0751 & -0.0720 & -0.0727 \\
\hline
\end{tabular}

${ }^{\text {a }}$ Notation of the type of atom is in Figure 1.

the complexes, it was observed that the $\mathrm{Cr}$ centers in $3 \mathrm{a}-3 \mathrm{c}$ lie in a distorted distorted octahedral environment. The $\mathrm{Cl}^{1}-\mathrm{Cr}^{-} \mathrm{Cl}^{3}$ bond angle is $175.904,176.195$ and 176.252 for the complexes $3 \mathrm{a}, 3 \mathrm{~b}$ and $3 \mathrm{c}$, respectively. The bond lengths of $\mathrm{Cr}-\mathrm{N}^{1}$ of the complexes $3 \mathrm{a}, 3 \mathrm{~b}$ and $3 \mathrm{c}$ are $2.807,2.801$ and $2.807 \AA$, respectively. The bond length of $\mathrm{Cr}-\mathrm{Cl} 1$ of the complexes 3a, $3 \mathrm{~b}$ and $3 \mathrm{c}$ are $2.378,2.388$ and $2.291 \AA$, respectively. These results show there are no conspicuous discrepancies in the bond angle and length among $3 \mathrm{a}-3 \mathrm{c}$.

The most commonly used methods to determine the atomic charges include the electrostatic potential (ESP) fitting ${ }^{15}$, Mulliken popular analysis ${ }^{16}$ and Hirshfeld popular analysis ${ }^{17}$.

Mulliken analysis largely depends on the basis set used and usually overestimates the charges, while Hirshfeld method usually underestimates the charge. In ESP method, the electrostatic potentials are fitted at grids located with equal density on different layers around the molecule. In this work, the atomic partial charges were obtained by ESP method (Figure 1). The charge of $\mathrm{Cr}$ calculated from $3 \mathrm{a}$ is 0.421 and it is smaller value than that of Cr from $3 b(0.546)$ and $3 c(0.537)$, revealing that the atomic charge is sensitive to the alkyl substituents on the bis(benzimidazolyl)amine ligand. The $\mathrm{Cr}$ atoms in the complexes bearing $\mathrm{N}$-benzyl and $\mathrm{N}$-methyl substituted ligands are more electro- positive than non-substituted ligands, as a result the electropositivity of $\mathrm{Cr}$ atom decreases in the order of $3 \mathrm{~b}>3 \mathrm{c}>3 \mathrm{a}$. However, on the basis of these calculations the electronic differences among the complexes appear to be less than are suggested by the differences in reactivity towards $\mathrm{BD}$.

A family of cobalt(II) complexes bearing the same tridentate bis(benzimidazolyl)amine ligands $\left(3 a^{6}, 3 b^{6}\right.$ and $3 c^{6}$ Table 2$)$ were found to produce PBDs with cis isomer content up to $97 \%$ in the presence of ethylaluminum sequichloride (EASC) as a cocatalyst. Electronic modulations of the complexes through $\mathrm{N}$-alkylation of the benzimidazolyl fragments had a significant effect on the catalytic activity but not on the stereospecificity. The catalytic behaviors of complexes $3 \mathrm{a}-3 \mathrm{c}$ for the polymerization of $\mathrm{BD}$ were studied at $50{ }^{\circ} \mathrm{C}$ combined with MAO (Table 2). Without co-catalysts or with other common alkylaluminums, the complexes exhibit only negligible activity for the polymerization of $\mathrm{BD}$. Upon activation with $\mathrm{MAO}, 3 \mathrm{a}$ polymerizes $\mathrm{BD}$ to give $\mathrm{PBD}$ in high yields. The PBD produced with $3 \mathrm{a} / \mathrm{MAO}$ is soluble in $\mathrm{CHCl}_{3}$, indicating crosslinking is negligible. The PBD obtained with $3 \mathrm{a} / \mathrm{MMAO}([\mathrm{Al}] /[\mathrm{Cr}]=1000)$ has low molecular weight $\left(\mathrm{M}_{\mathrm{n}}\right.$ $=9800 \mathrm{gmol}^{-1}$ ) and moderately narrow molecular weight distribution $\left(\mathrm{M}_{\mathrm{w}} / \mathrm{M}_{\mathrm{n}}=3.18\right)$. 3b/MAO and 3c/MAO catalyst systems also show quite high yields, 41.7 and $56.9 \%$, respectively, polymerizations under the same conditions. As a result the activity decreases in the order of $3 a>3 c>3 b$. Interestingly this order is reversely in line with the the electropositivity of $\mathrm{Cr}$ atom.

Table 2. Results of BD polymerizations by $\mathrm{Cr}$ (III) complexes, 3a-3c, combined with MAO. Conditions: catalyst $=1.1 \mu \mathrm{mol}$, $[\mathrm{BD}]=0.7 \mathrm{M}$, reaction volume $=20 \mathrm{~mL}$, time $=1 \mathrm{~h}$, and

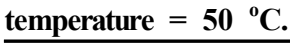

\begin{tabular}{|c|c|c|c|c|c|c|c|c|}
\hline \multirow[b]{2}{*}{ Cat. $^{\mathrm{a}}$} & \multirow[b]{2}{*}{ Cocat. } & \multirow{2}{*}{$\begin{array}{l}\mathrm{Al} / \\
\mathrm{Cr}\end{array}$} & \multirow[b]{2}{*}{ Yield (\%) } & \multirow[b]{2}{*}{$\mathrm{M}_{n} \times 10^{-3}$} & \multicolumn{4}{|c|}{$\mathrm{M}_{\mathrm{w}} \quad$ Microstructure $^{\mathrm{b}}(\%)$} \\
\hline & & & & & $\begin{array}{c}\text { / } \\
\mathrm{M}_{n}\end{array}$ & 1,4-cis & 1,4-trans & 1,2 \\
\hline $3 a$ & MAO & 400 & 66.6 & 12.0 & 3.18 & 0 & 100 & 0 \\
\hline $3 a$ & MAO & 1000 & 81.4 & 9.8 & 2.76 & 0 & 100 & 0 \\
\hline $3 a$ & MAO & 6000 & 81.0 & 7.9 & 2.57 & 0 & 100 & 0 \\
\hline $3 a$ & EASC $^{\mathrm{c}}$ & 400 & trace & - & - & 0 & 100 & 0 \\
\hline $3 a^{\prime}$ & EASC & 400 & 65.8 & 159 & 3.21 & 94.7 & 3.0 & 2.3 \\
\hline $3 b$ & MAO & 1000 & 41.7 & 11.7 & 2.54 & 0 & 100 & 0 \\
\hline $3 b^{\prime}$ & EASC & 400 & 37.6 & 173 & 2.43 & 93.4 & 2.5 & 4.1 \\
\hline $3 \mathrm{c}$ & MAO & 1000 & 56.9 & 19.1 & 2.49 & 0 & 100 & 0 \\
\hline $3 c^{\prime}$ & EASC & 400 & 61.2 & 160 & 3.34 & 96.6 & 2.2 & 1.2 \\
\hline
\end{tabular}

a $3 a^{\prime}, 3 b^{\prime}$ and $3 c^{\prime}$ are Co(II) dichloride complex bearing the ligand $1,2 \mathrm{a}$ and $2 \mathrm{~b}$, respectively. ${ }^{11}$ Polymerizations using these complexes were performed at the same conditions except polymerization time of $10 \mathrm{~min}$.

${ }^{b}$ Measured by ${ }^{1} \mathrm{H}$ and ${ }^{13} \mathrm{C}$ NMR spectroscopies.

c Polymerizations combined with other alkylaluminums such as methylaluminum dichloride and diethylaluminum chloride showed only negligible activities. 

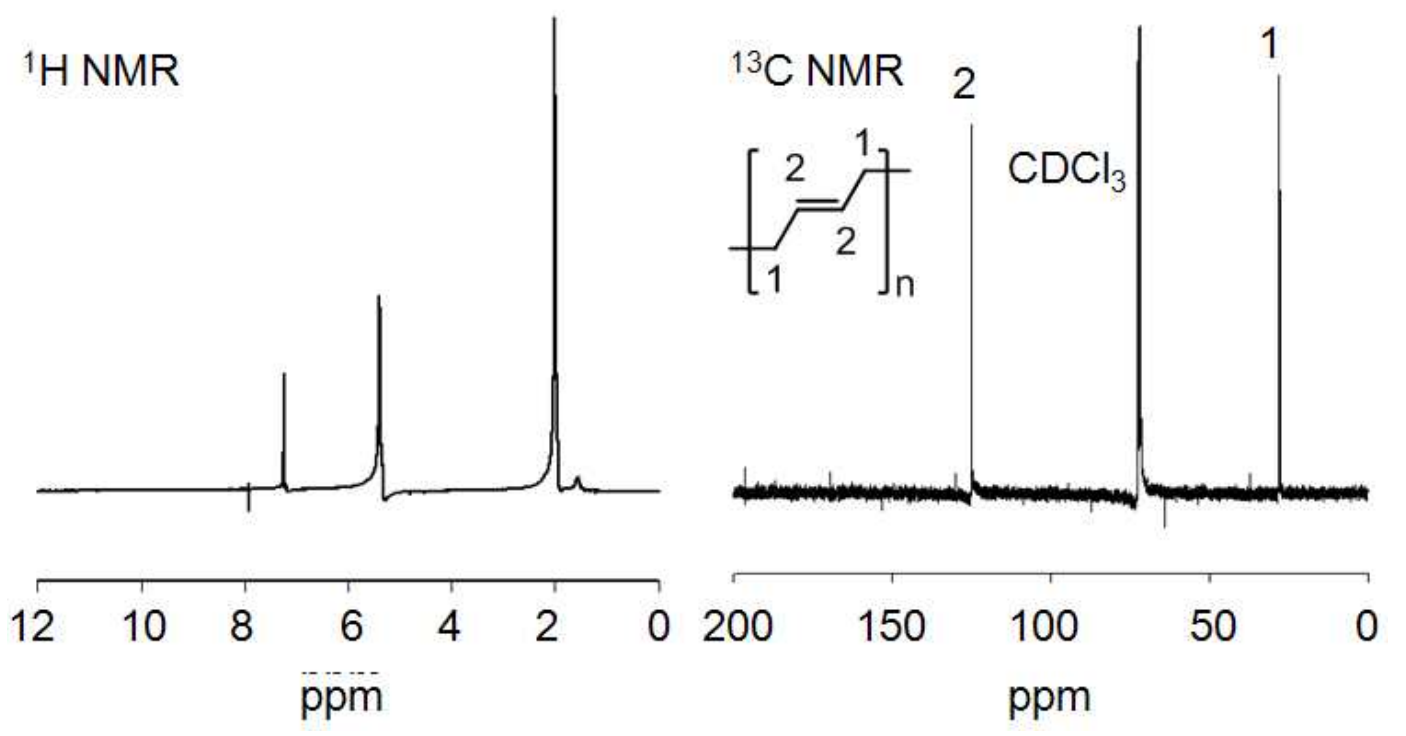

Figure 2. ${ }^{1} \mathrm{H}$ and ${ }^{13} \mathrm{C}$ NMR spectra of $\mathrm{PBD}$ obtained by $3 \mathrm{a} / \mathrm{MAO}$ catalyst system with $\mathrm{Al} / \mathrm{Cr}$ ratio of 1000 . Polymerization conditions are in Table 1.

Figure 2 shows the ${ }^{1} \mathrm{H}$ and ${ }^{13} \mathrm{C}$ NMR spectra of PBD obtained by $3 \mathrm{a} / \mathrm{MAO}(\mathrm{Al} / \mathrm{Cr}=1000)$ catalyst. The ${ }^{13} \mathrm{C}$ NMR spectrum of the PBD exhibits a set of sharp singlet peaks at 130.0 and 32.7 ppm assignable to trans-1,4- units, and no other signals assignable to $c i s-1,4-$ or 1,2 units are detected. ${ }^{18}$ This indicates that the PBD obtained has a perfect trans-1,4 structure. The trans-1,4-PBD is crystalline and shows two melting points at $76.8{ }^{\circ} \mathrm{C}\left(\Delta H_{\mathrm{m}}=145.9\right.$ $\left.\mathrm{J} \mathrm{g}^{-1}\right)$ and $136.1{ }^{\circ} \mathrm{C}\left(\left(\Delta H_{\mathrm{m}}=61.3 \mathrm{~J} \mathrm{~g}^{-1}\right)\right.$. There are some examples of catalyst systems to produce trans-1,4-PBD consisting of transition metals such as lanthanoids, chromium, cobalt, iron, rhodium, titanium, and vanadium. ${ }^{3}$ The present $\mathbf{3 a}$ /MAO system is one of the most trans-1,4-specific catalysts for BD polymerization. Detailed modification of the ligand, followed by kinetic study of BD polymerization is ongoing and is to be published elsewhere.

\section{Conclusions}

The readily accessible tridentate dibenzimidazolyl ligand was found to stabilize active BD polymerization catalysts based on $\mathrm{Cr}$ (III). The activity of BD polymerizations was sensitive to the type of ligand on the $\mathrm{Cr}$ metal, so that the activity decreases in the order of $3 a>3 c>3 b$. All the catalysts combined with MAO yielded PBDs with perfect trans-1,4 structure with moderate molecular weight.

\section{Acknowledgments.}

This work was supported by grants-in-aid for the World Class University Program (No. R32-2008-000-10174-0) and the Fundamental Research \& Development Program for Core Technology of Materials (Ministry of Knowledge Economy, Republic of Korea).

\section{References}

1. Thiele S K H and Wilson D R, J. Macromol. Sci. C: Polym. Rev., C43, 581 (2003).

2. L. Friebe, O. Nuyken and W. Obrecht, Adv. Polym. Sci., 204, 1 (2006).

3. Ricci G, Sommazzi, A, Masi F, Ricci M, Bogliaa A, and G. Leonea, Coord. Chem. Rev., 254, 661 (2010).

4. Peluso A, Improta R, and Zambelli A, Organometallics, 19, 411 (2000).

5. Tobisch, S, Organometallics, 22, 2729 (2003).

6. Costabile C, Guerra G, Longo P, and Pragliola S, Macromolecules, 37, 2016 (2004).

7. Iwamoto M and Yuguchi S, Polym. Lett., 5, 1007 (1967).

8. Hermes A R and Girolami G S, Inorg. Chem., 27, 1775 (1988).

9. Nakayama Y, Sogo K, Cai Z, Yasuda H, and Shiono T, Polym. Int., 60, 692 (2011).

10. Bianchini C, Mantovani G, Meli A, Migliacci F, Zanobini F, Laschi F, and Sommazzi A, Eur. J. Inorg. Chem., 1620 
(2003)

11. Appukuttan V, Zhang L, Ha C-S, and I Kim, Polymer, 50, 1150 (2009).

12. Kwaskowska-Chec E, Kubiak M, Glowiak T, and Ziolkowski J J, J. Chem. Crystallogr., 25, 37 (1995).

13. Lee G M, Appukuttan V K, Suh H, Ha S -S, and Kim I, Catal. Lett., 141, 1608 (2011).
14. Perdew J P and Wang Y, Phys. Rev. B, 45, 13244 (1992).

15. Bakalarski G, Grochowski P, Kwiatkowski J S, Lesyng B, and Leszczynski J, Chem. Phys., 204, 301 (1996).

16. Mulliken R S, J. Chem. Phys., 23, 1833 (1955).

17. Hirshfeld F L, Theor. Chim. Acta B, 44, 129 (1977).

18. Sato H, Takebayashi K, and Tanaka Y, Macromolecules, 20, 2418 (1987). 